\title{
ナノ金属安定化炭素
}

\section{Carbons stabilizing nanometals}

\section{加納博文*}

Hirofumi Kanoh*

\begin{abstract}
Nanoporous metals and nanometals need stabilizers which prevent them from sintering or oxidizing. Nanoporous Pt, Ni, or $\mathrm{Pd}$, which were prepared by using silica nanoparticles or PVA films as templates, can be stabilized by a trace or small amount of carbons, which coat surfaces of the metals. Also, single wall carbon nanohorn can be a good stabilizer and catalyst support. The properties of such nanocarbons are reviewed for stabilization of nanometals.
\end{abstract}

\section{KEYWORDS : Nanoporous metals, Nanometals, Templating methods, Single wall nanocarbons}

\section{1.はじめに}

著者が研究の対象としている物質はナノ細孔体と呼ばれる物 質群で, その代表としてゼオライトや活性炭がある。ゼオライトは ケイ酸アルミニウムやシリカ, あるいはリン酸アルミニウムから なる物質で結晶性のナノ細孔体としてよく知られている。また, ゼオライト系に属する,規則正しいシリンダー状ナノ細孔をもつ物 質として,メソポーラスシリカがある。これは界面活性剤の棒状ミ セル集合体がテンプレートとして作用して合成されるものであ る。この場合壁のケイ酸は結晶ではないが, 1本1本のシリンダ 一が最密充填構造を形成し,集合体が規則性を示す。最近盛んに 研究されているナノ細孔体の1つに配位高分子 (Coordination Polymer (CP)) あるいは Metal Organic Framework (MOF) と呼 ばれる結晶性ナノ細孔体がある。以上に挙げた物質は基本的に は電気的にも熱的にも伝導性の悪い物質と言ってよい。

一方, 活性炭は炭素網面を基本骨格とするので, 比較的電気伝 導性に優れ，それゅ等伝導性も高い。工業的によく用いられて いるヤシガラ活性炭にはさまざまな細孔が存在するが, 細孔径分布 が広く表面官能基が比較的多いため, 基礎研究の対象とするには 素性がよくわかった物質とは言えない。それに比べ活性炭素瀻 維 $(\mathrm{ACF})$ は, $1 \mathrm{~nm}$ 前後の比較的そろった細孔を有するミク口細 孔体で, 官能基も比較的少なく, あるいは制御可能なので, 広く基 礎研究に用いられてきている。また, メソポーラスシリカをテン プレートとして得られるカーボン系のメソ細孔体もあり,テンプ レートの種類を選択することでさまざまなナノ細孔性物質を調 製することが可能である。これら物質は結晶ではなくアモルフ アス物質であるが, フラーレンやナノチューブは結晶を形成する。 単層ナノチューブの壁はグラフェーンと呼ばれる炭素の二次元結 晶で構成されており，それが丸まってでき上がったものがナノチ ユーブである。炭素原子は規則正しく並んでいるので二次元的
結晶なのであるが，均一な単層ナノチューブが集合体を形成する と,今度はチューブが規則正しく並んだ結晶とも言えるバンドル構 造を形成する。フラーレンの場合は分子性結晶を形成する。こ れら炭素系ナノ細孔体は比較的高い電気伝導性と熱伝導性の特 徵をもつ。

炭素系物質のもう $1 つ の$ 特徵として, 還元性が挙げられる。こ の性質は金属ナノ粒子の保護という観点から重要である。ナノ 粒子は表面の割合が大きいので, 不安定であり, 焼結して大きな 粒子になろうとするか, 金属が酸素䨌囲気下にあれば酸化物を形 成しょうとする。しかしながら, 還元性の炭素が金属ナノ粒子の 周りを囲めば, 焼結や酸化に対して保護する作用をもつであろう。 本稿ではこのような炭素をナノ金属安定化炭素と呼ぶ。

還元性の炭素材といってもバルク物質であるグラファイトと グラフェーン 1 枚からなる単層ナノカーボンの作用は異なるであ ろう。特に金属ナノ粒子の機能として期待される触媒作用につ いて,ナノカーボンに担持した場合の報告例がいくつかあるが, 担 体の効果について詳細に調べた例はそれほど多くないと見受け られる。ここでは, 市販の活性炭と単層ナノカーボンの担体効果 について調べた結果も併せて,ナノ金属安定化炭素について紹介 することとする。

\section{2. ナノ細孔性金属の現状}

先に述べたように, 金属ナノ粒子は高真空下極低温では安定に 存在すると期待されるが, 温度が高くなったり, 反応活性のある 雾囲気ガスが存在するともはや安定ではなくなり, 焼結や酸化反 応が進行することになる。そこで, 金属ナノ粒子を調製するために, 表面保護材の導入が必要となる。例えば, ポリビニルプロリドン (PVP) を用いてパラジウムナノ粒子の調製が報告されている1),2。 著者らは金属自身にナノ細孔を賦与できないかを検討してきて いるが,一部そういったナノ細孔性金属,すなわち, 高表面な細孔

* Corresponding Author, E-mail: kanoh@pchem2.s.chiba-u.ac.jp (平成20年8月25日受理, 平成20年 10 月2 日採択) 千葉大学大学院理学研究科：=263-8522 千葉市稻毛区弥生町 1-33

Graduate School of Science, Chiba University : 1-33 Yayoi-cho, Inage, Chiba 263-8522, Japan 
性金属を調製できたので紹介する。

球状粒子の比表面積は密度と直径の関数となるが, ガラスや 活性炭のように密度 $2 \mathrm{~g} / \mathrm{cm}^{3}$ 程度の場合, 直径 $10 \mathrm{~nm}$ で比表面積 $300 \mathrm{~m}^{2} / \mathrm{g}$, 直径 $2 \mathrm{~nm}$ で比表面積 $1,500 \mathrm{~m}^{2} / \mathrm{g}$ と計算される。一方, 白金の密度 $21.5 \mathrm{~g} / \mathrm{cm}^{3}$ では, 直径 $10 \mathrm{~nm}$ で比表面積 $28 \mathrm{~m}^{2} / \mathrm{g}$, 直径 $2 \mathrm{~nm}$ で比表面積 $140 \mathrm{~m}^{2} / \mathrm{g}$ となり, 密度の高い金属では比表面積 $100 \mathrm{~m}^{2} / \mathrm{g}$ 程度でも高度なナノ構造をもつ物質であることがわかる。

ナノ細孔性金属に関する研究成果が報告されるようになったの は比較的最近で, Attardのグループによるものが最初であろう3)-9)。 このグループは界面活性剤のリオトロピック液晶をテンプレート として用いる方法で, 六方晶ナノ構造を有する白金ナノ細孔体を 創製した。しかしながら, 気体吸着法による表面積の測定による とせいぜい $60 \mathrm{~m}^{2} / \mathrm{g}$ であり, 白金黒の $20 \sim 30 \mathrm{~m}^{2} / \mathrm{g}$ の 2 倍程度の 比表面積である。電極触媒としての応用を目指した研究のため, 気体吸着性に関する検討はあまりなされていない。

気体吸着性を評価した研究として, Wakayama and Fukushima の報告がある10)，11。白金化合物アセトン溶液と活性炭素繊維を 耐圧容器に入れ, 活性炭素纎維が溶液に浸らないようにバスケット に吊るした状態でセットする。これを加圧・加熱し, $423 \mathrm{~K}, 32 \mathrm{MPa}$ の条件で 2 時間, 超臨界二酸化炭素中で処理する。すなわち, 活 性炭素繊維のナノ細孔をテンプレートとして用いている。その 後, 白金化合物が担持された活性炭を $873 \mathrm{~K}$ で焼成したり，ある いはプラズマ酸化で焼成することにより炭素分を除去し, 白金ナ

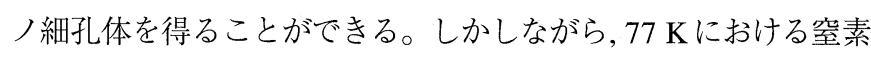
吸着から得られるBET 比表面積は $47 \mathrm{~m}^{2} / \mathrm{g}$ とAttard のグループの ものより小さく, 活性炭素繊維を形態制御のためのテンプレート として用いるのが主目的の研究である。

著者らの研究グループでは, より工業的な観点から簡便な方法 で白金ナノ細孔体の合成を検討した12)。白金化合物を,テンプレ ートである非細孔性シリカ微粒子の表面にコーティングし, 還元後 シリカを除くという, 比較的簡便な方法で白金カプセル様のナノ 細孔体を合成した。しかしながら，この状態では溶媒で用いた アセトンから生じる炭素分が多く残っており,これを除くために

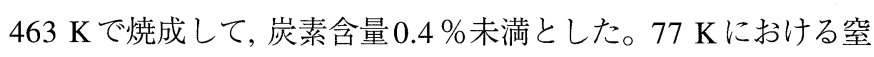
素吸着法により BET 比表面積として $91 \mathrm{~m}^{2} / \mathrm{g}$ の值が得られてお り, 金属白金としては最高の表面積を有する物質である。具体的 方法について以下に述べる。

貴金属ではないが遷移金属であるニッケルナノ細孔体の調製 に成功した。Hattoriらによるニッケルナノ細孔体がある13)。こ れはポリビニルアルコール (PVA) 高分子マトリックス内の微小 空間をテンプレートとして, 空間内に水酸化ニッケルの微粒子を 形成させ, その後PVA を焼成して除くとニッケルナノ粒子が生成 するというものであり, 窒素吸着からのBET 比表面積は $121 \mathrm{~m}^{2} / \mathrm{g}$ と得られており,ナノ細孔構造が確認された。この方法を利用す ると,簡便に金属ナノ粒子を調製できることがわかった。本方法 を用いたパラジウムナノ粒子の調製方法について, 後に述べる。

ほかにもシリカ構造体をテンプレートしてメタルナノワイヤ ー14)，15）を合成した報告もあるが, BET 比表面積の評価はなく,
どれだけのナノ細孔性を有するかは不明である。最近, 界面活性 剤をテンプレートとして用いる方法によって,ナノシートができ る報告16）もあるが, BET 比表面積は $20 \mathrm{~m}^{2} / \mathrm{g}$ 程度であり, 細孔性 としては先述のAttardらのものより小さい。

\section{3. シリカテンプレート法によるナノ細孔性白金12)}

合成はテンプレートとしてノンポーラスシリカナノ粒子を用 い, 白金化合物で表面を覆い, 加熱還元した後, アルカリ処理して シリカを溶解・除去するという比較的簡便な方法である。

具体的にはテンプレートとして平均粒径 $20 \mathrm{~nm}$ のシリカナノ 粒子を用い,これを真空加熱処理して表面や粒子間に吸着してい る物質を除いた後, 真空下でへキサクロロ白金酸のアセトン溶液 に懸濁し, シリカ粒子表面におけるへキサクロロ白金酸のコーティ ング反応を進行させる。反応終了後, 減圧条件下で濃縮乾固させ る。これをへキサクロロ白金酸の分解温度以上の $450{ }^{\circ} \mathrm{C}$ に加熱 して還元すると, シリカ表面に白金が薄くコーティングした白 金一シリカナノ複合体が得られる。これに水酸化ナトリウム溶 液を加えてアルカリ処理することで, シリカ成分を溶解除去でき, 生成物を得ることができる。ただし, 本生成物はBET比表面積 $232 \mathrm{~m}^{2} / \mathrm{g}$ と高い細孔性を示すが, $20 \%$ 程度の炭素を含むことがわ かっており，これでは白金ナノ細孔体ということはできない。そ こで, これを空気中 $463 \mathrm{~K} て ゙$ 焼成することで炭素分を燃焼させ, $0.37 \%$ 炭素含量とし, 微量炭素によって安定化された白金ナノ 細孔体が得られる。本物質は, X 線回折法やX線光電子分光法に より白金金属であることが確認された。X線回折ピークの半価 幅からシェラーの式を用いて計算すると, 結晶子の大きさとして $12 \mathrm{~nm}$ と見積もられる。

Fig.1に生成物の走査型電子顕微鏡写真を示す。Fig.1a）はア ルカリ処理してシリカを溶解除去して得られた生成物の顕微鏡 像で, $20 \%$ 前後の炭素分を含むがこの像からはその存在はよくわ からない。確認される粒子は平均 $20 \sim 30 \mathrm{~nm}$ の球状をしており, テンプレートのシリカ粒子に似た形状である。したがって, 白金 がシリカ表面を被覆し, 還元されることにより白金がシリカ微粒子 を被覆した白金ーシリカ複合体を形成すると考えられる。Fig.1b) は463 Kで空気中加熱焼成して炭素分を除去したもので, 星型に 広がった形のものも見られる。炭素が粒子内部にあり, 加熱焼成 の際, 炭素が二酸化炭素となって放出する際, 白金の殼が破裂し て星型形状を呈したと考えられる。こうして得られた微量炭素 安定化白金ナノ細孔体は, BET 比表面積 $91 \mathrm{~m}^{2} / \mathrm{g}$ と, 市販の白金 黒の3 倍以上のナノ細孔性を示す。窒素吸着等温線の解析から, ミクロ細孔と $20 \mathrm{~nm}$ 以下のメソ細孔を有し, 気体分子吸着による 測定ではこれほど高い比表面積を有する金属白金は報告されて おらず, 高度にナノ構造が発達した物質である。

この物質を用いて, 液相における電気化学触媒活性と気体の触 媒活性について検討した17)。電気化学触媒としては,グラッシー カーボンに上記で得られたナノ細孔性白金を載せて硫酸中のメ タノールの酸化反応を調べた。市販の白金黒と比較して, 比活性 については同等であったが, 繰り返し過程で起こるCO被毒の影 

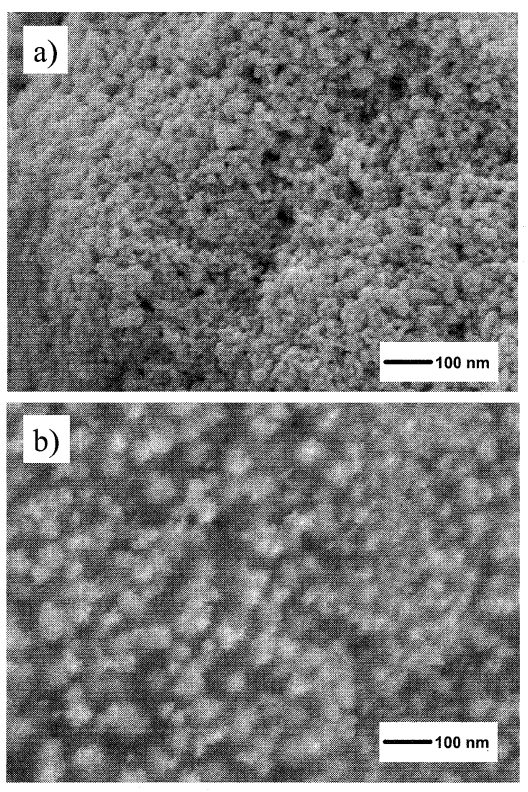

Fig.1 SEM images : a) Nanoporous Pt-carbon composite ; b) Nanoporous metallic Pt.

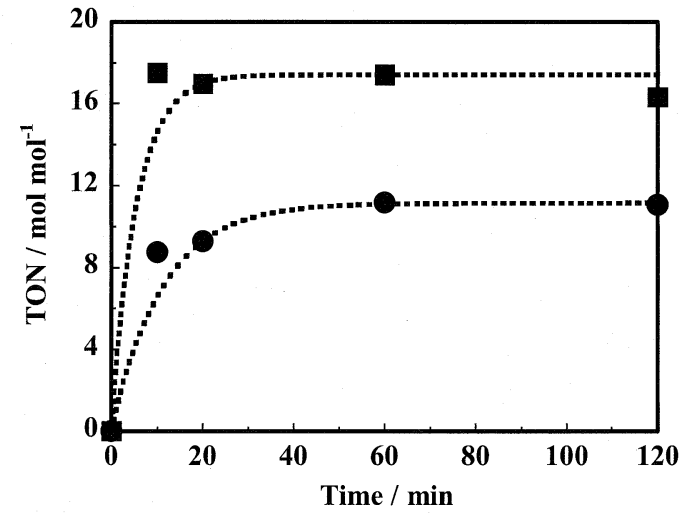

Fig.2 Time courses of TON of gaseous reaction $\mathrm{H}_{2}+(1 / 2) \mathrm{O}_{2} \rightarrow$ $\mathrm{H}_{2} \mathrm{O}$.

口 : Nanoporous metallic Pt ; : Pt black (commercial)

響については軽減されることがわかった。また, 水素と酸素が反応 して水になるという気相反応の触媒活性は市販の白金黒より明 らかに優位であることを示した。小さなナノ細孔への溶液中で の溶媒和したイオンや脱水過程を経て生じた裸のイオンの拡散 過程は比較的遅く, 溶液中での活性に対してナノ細孔性はあまり 有効ではないのかもしれない。一方, 室温における気相では拡散が 十分速く,ナノ細孔性による反応活性の向上が見られるのであろ う。Fig.2には,ナノ細孔性白金と白金黒の水素と酸素の気相反 応に対する活性の時間変化を示す。ターンオーバーナンバーの 時間変化はほほ同程度であるが,ナノ細孔性白金は約 1.5 倍の比 活性を示すことから,ナノ細孔性の特徴を示す結果と見てよい。

\section{4. ポリビニルアルコール (PVA) 膜テンプレート法によ るナノ細孔性金属の調製}

\section{1 ナノ細孔性ニッケル13)}

PVA は水溶液をキャスティングして乾燥することで簡単に膜に

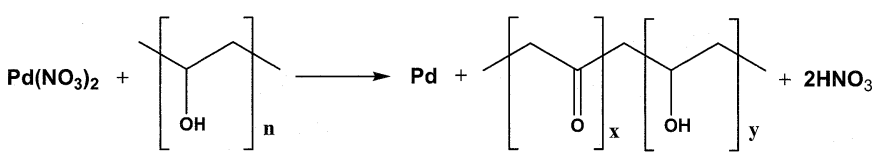

Scheme 1 Reduction of Pd (II) by PVA.
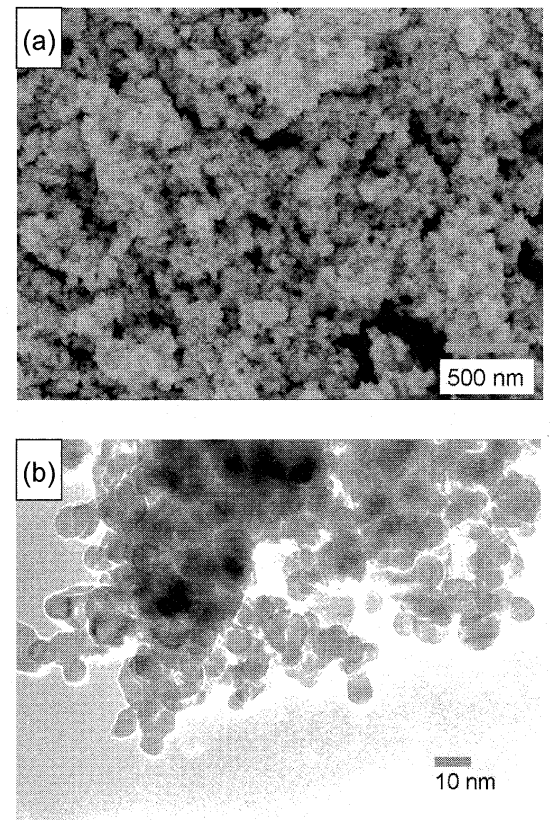

Fig.3 SEM images of nanoporous metallic Pd at (a) low magnification and at (b) high magunification.

できるが, この膜を $30 \mathrm{wt}$ \%硝酸ニッケル溶液に3 日間浸すとニッケ ルイオンがPVA高分子が形成するマトリックスに浸透し, 溶液中 と同様の形態で存在すると考えられる。これを $1 \mathrm{M}$ 水酸化ナトリ ウムに3 日間浸すと水酸化ニッケル沈殿がPVA膜マトリックスで 生じる。膜乾燥後のニッケル含量は $35 \mathrm{wt} \%$ と高く, これを窒素気 流下 $923 \mathrm{~K}$ で焼成する。PVA と水酸化ニッケルの酸素が膜を燃焼 させ, 最終的にニッケル金属が得られる。得られた試料のX線回 折法, $\mathrm{X}$ 線光電子分光法, $\mathrm{X}$ 線吸収法によって, ニッケル金属であ ることが確認された。X線回折ピークの半価幅から平均結晶子径 として $8.3 \mathrm{~nm}$, 窒素吸着測定から BET 比表面積 $121 \mathrm{~m}^{2} / \mathrm{g}$ が得られ, ミクロ孔と2〜10 nmのメソ孔を有する物質であることがわかる。 電顕写真でもそのようなナノ細孔性を確認できた。

ニッケル金属がナノ構造を保つことができる機構としては微 量炭素の存在が考えられている。X線光電子分光法によると極 表面の酸素はほとんど存在せず, 微量の炭素が存在することが示 唆され,この物質においても微量炭素がナノ構造性ニッケル金属 を安定化させていると考えられる。したがって, 窒素気流中での焼 成における炭素と酸素のバランスがうまく働いてニッケルナノ細 孔体を生成させるといってよい。

\section{2 ナノ細孔性パラジウム ${ }^{18)}$}

同様に硝酸パラジウムの硝酸溶液に, PVAキャスティング膜を $\mathrm{Pd}\left(\mathrm{NO}_{3}\right)_{2}$-硝酸水溶液浸漬し, 超音波をかけ1日放置する。この 場合, PVAが $\mathrm{Pd}^{2}+$ を還元しパラジウム金属となる $($ Scheme 1)。 


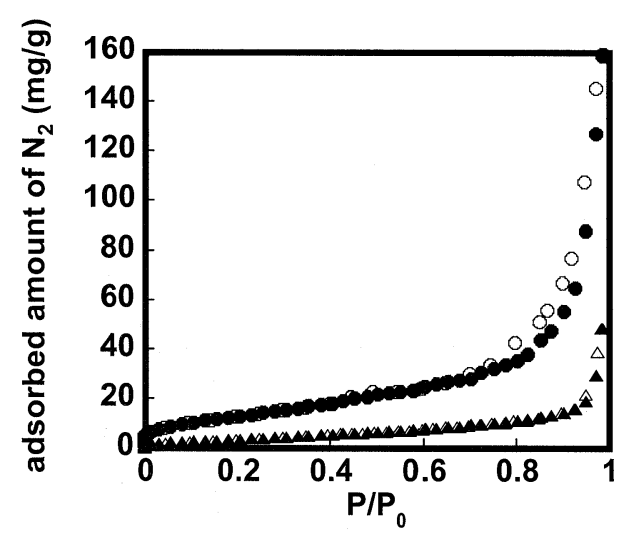

Fig.4 $\mathrm{N}_{2}$ adsorption isotherm at $77 \mathrm{~K}$.

Circle : Nanoporous metallic Pd, Triangle : Pd black (commercial)

Closed : Adsorption, open : Desorption

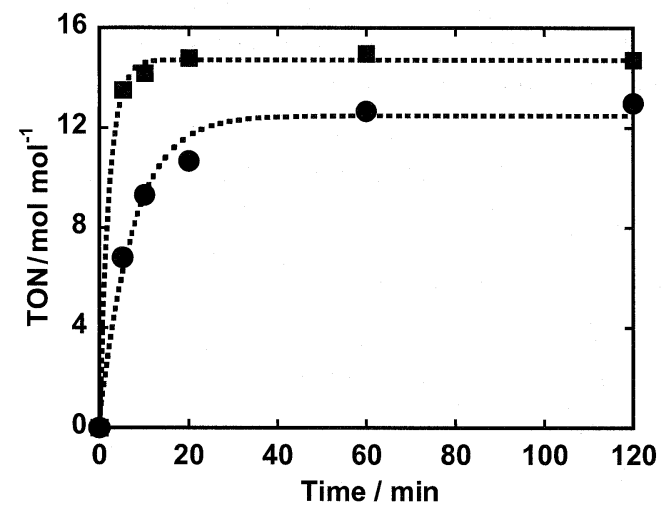

Fig.5 Time courses of TON of gaseous reaction $\mathrm{H}_{2}+(1 / 2) \mathrm{O}_{2} \rightarrow$ $\mathrm{H}_{2} \mathrm{O}$.

- Nanoporous metallic Pd, : Pd black (commercial)

その後水洗して得られる物質は,パラジウムがポリマーに囲まれ たものであるので, これを除去するために $2 \mathrm{M} \mathrm{NaOH}$ 水溶液に入 れ, $383 \mathrm{~K}$ で水熱処理すると金属周りのポリマーが溶解してナノ 細孔性パラジウムが得られる。こうして得たナノ細孔性パラジ ウムは熱分析から $94 \%$ \%金属であることがわかった。また, X線 回折から, 結晶子の大きさとして $8 \mathrm{~nm}$ と見積もられ, 電子顕微鏡 像との一致が確認された $($ Fig.3)。77 K における窒素吸着等温線 の測定結果 (Fig.4) からも, パラジウム黒の4倍近いBET 比表面 積 $37 \mathrm{~m}^{2} / \mathrm{g}$ とミクロ細孔容量 $8.8 \mathrm{~mm}^{3} / \mathrm{g}$ が得られた。Fig.2で示し た気相触媒反応に対して, パラジウム黒と比較したところ, 反応 速度, 比活性ともにパラジウム黒より良好で, この場合でもナノ 細孔の有効性が示された $($ Fig.5)。

本方法は, 非常に簡便な方法でナノ細孔性金属を調製できると いう点で, 応用性が高い手法であると言える。実用的な観点から の研究開発について期待している。

\section{5. 単層カーボンナノホーンに担持された金属ナノ粒子24), 25)}

金属や金属酸化物のナノ粒子を単層カーボンナノホーン (以後 SWCNH と略す) に担持する方法や得られたコンポジットの反応活 性について著者らのものも含め,いくつか報告されている2), 19)-23)。

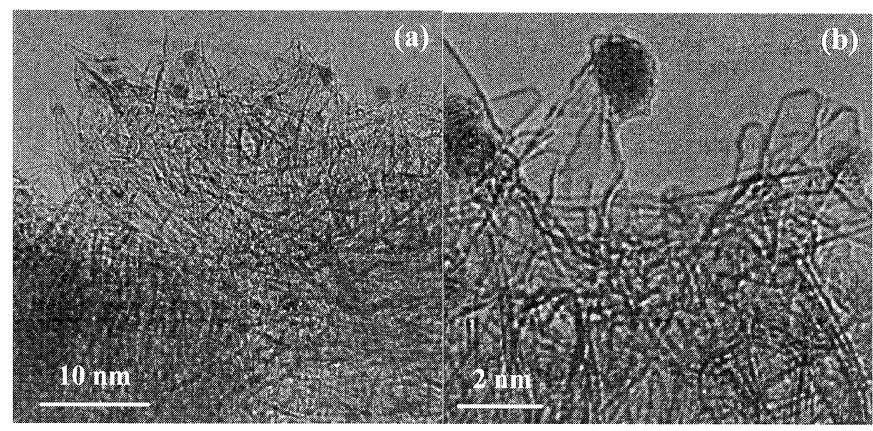

Fig.6 TEM images of Pdpvp-oxSWCNH (a) at low magnification and (b) at high magnification.

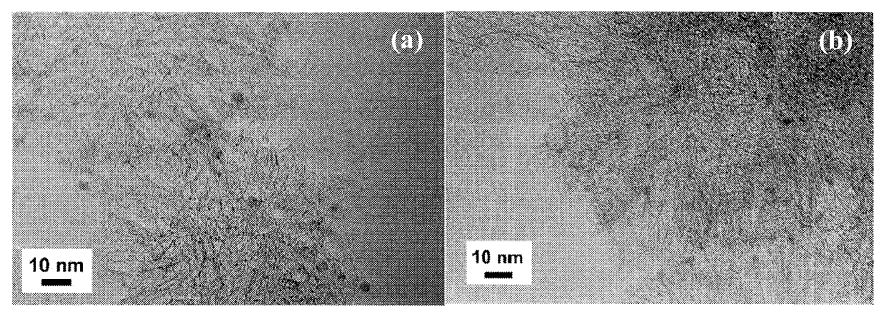

Fig.7 TEM images of (a) Pd-SWCNH and (b) Pd-oxSWCNH.

その中にはPVPで被覆されたパラジウムナノ粒子を担持する方 法がある。この場合, 基本的にはPVPの被覆効果が触媒反応特 性に関係すると考えられる。これとは別に, PVPで被覆せず直接 パラジウムナノ粒子を担持したものについても, 調製法と触媒活性 を検討した。その一例についても併せて紹介する。

担体として用いるSWCNH はアルゴン雾囲気下, 室温でグラフ アイトをターゲットとして, 二酸化炭素レーザーアブレーション 法で調製されたものである26)。また, 酸素気流下 10 分間 $823 \mathrm{~K}$ で処理し, SWCNHの壁にナノレベルの孔を形成させた酸化処理 SWCNH (以後oxSWCNH と略す) も担体として用いた27)。これ ら SWCNH およびoxSWCNHをあらかじめPVPで被覆したパラ ジウムナノ粒子分散液に加え還流することで, SWCNH 抢よび oxSWCNHに担持したパラジウムナ)粒子(それぞれP $\mathrm{d}_{\mathrm{PVP}}$ SWCNH と PdPVP-oxSWCNH と表記) を得た。PdPVP-oxSWCNH のTEM像を Fig.6に示す。これとは別に, 酢酸パラジウムトルエン 溶液にSWCNH および oxSWCNHを加え超音波処理し, その後工 タノールを加えて金属に還元し, さらに超音波処理して得たPVP 被覆のない試料をPd-SWCNH とPd-oxSWCNH として表記する。 これらのTEM像をFig.7に示す。Fig.6と Fig.7からそれぞれ2 $3 \mathrm{~nm}$ の直径のPd粒子がSWCNHのホーン部分に適度に分散して いるように見える。PVPの被覆をするか否かでナノ粒子の大き さや分散性に大きな違いはないようである。

PVPで被覆したパラジウムナノ粒子を担持した試料の気相に おける水生成反応の触媒活性の結果を Fig.8 に示す。比較のため に活性炭にパラジウムが担持されたもの（市販品：Pd-ACと表 示), また, 上述した方法で ACFに担持したパラジウムナノ粒子 の結果も示してある。明らかにSWCNHに担持したパラジウム

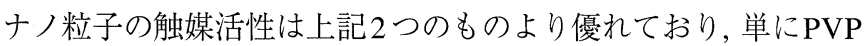




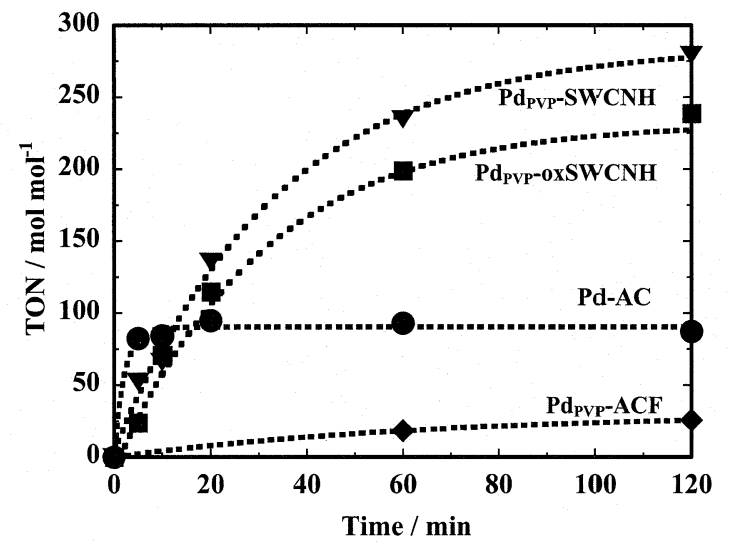

Fig.8 TON for water formation reaction at $273 \mathrm{~K}$ over $\mathrm{Pd}_{\mathrm{PVP}}-$ SWCNH, PdPV-OxSWCNH, PdPVP-ACF, and Pd-ACs catalysts. Thermogravimetric analyses showed that both $\mathrm{Pd}_{\mathrm{PVP}}-\mathrm{SWCNH}$ and PdPVP-OxSWCNHs contain $2.6 \mathrm{wt} \%$ of Pd. The Pd loading of Pd-AC and PdPVP-ACF were 11.2 and $3.3 \mathrm{wt} \%$ respectively. $1 \mathrm{mg}$ of each sample was used for the measurement.

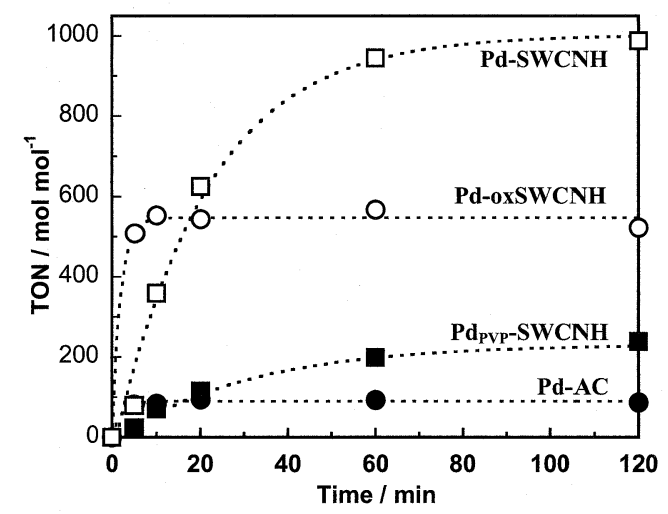

Fig.9 TON for water formation reaction at $273 \mathrm{~K}$ over Pd-SWCNH,

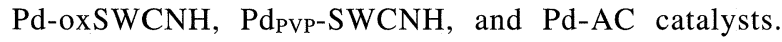
Thermogravimetric analyses showed that Pd-SWCNH and Pd-oxSWCNH contain 0.8 and $1.3 \mathrm{wt} \%$, respectively, of Pd. The Pd loading of PdPvP-SWCNH and Pd-AC were 1.1 and $6.8 \mathrm{wt} \%$ respectively. $1 \mathrm{mg}$ of each sample was used for the measurement.

の被覆効果たけけではない別の効果が関係するものと思われる。例 えば, Pd-ACのパラジウムの一次粒子はナノ粒子かもしれないが, 凝集したマイクロメートルオーダーのものが活性炭の表面に見ら れるので, たとえナノメートルサイズの粒子があっても Pd mol 当 たりで換算した場合, TON はかなり低くなると考えられる。PdPVPACFについては詳細な検討をしていないが, 分散状態が悪いため であろうと推測している。

次にFig.9に扔いてPVPの被覆効果について示す。P $\mathrm{Pd}_{\mathrm{PVP}}$ $\mathrm{SWCNH}$ とPd-SWCNH とを比べると, 明らかにPVP被覆のない 後者のほうの比活性が高いことがわかる。また, PVP 被覆のない 場合, Pd-oxSWCNH は活性の立ち上がり, すなわち初期活性は高 いがすぐに飽和してしまうことがわかる。それに比べ, PdSWCNHは60分程度まで緩やかに活性が上がり, 1.4 倍程度の高

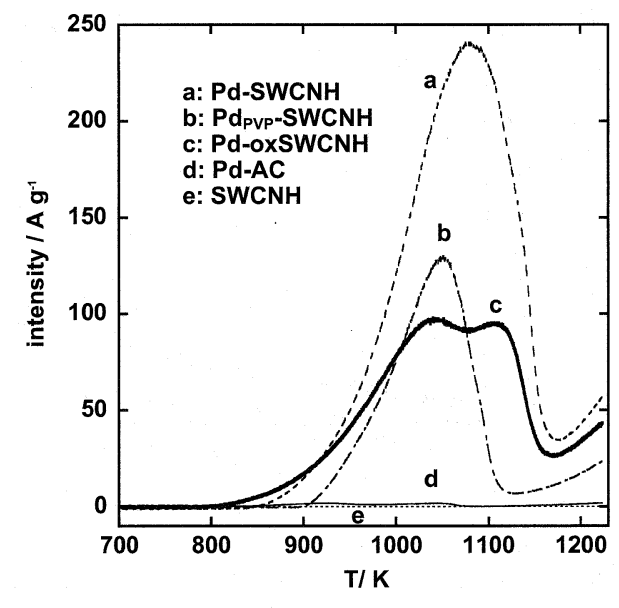

Fig.10 Temperature dependence of intensity $(\mathrm{m} / \mathrm{e}=2)$ for hydrogen formation reaction by methane decomposition over Pd-

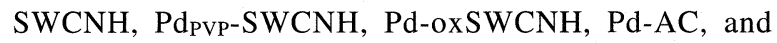
SWCNH catalysts. $15.0 \mathrm{mg}$ of samples was used except for Pd-AC, whose $21.5 \mathrm{mg}$ was used.

いTONを示す。Pd-oxSWCNH は官能基由来の酸素があるため に, 初期活性は酸化パラジウムによる酸化反応が進行するためと 考えられる。このような結果はメタン分解による水素生成反応 に対しても見られる。

Fig.10に水素生成量に対応する四重極質量分析計の質量数 2 の 強度を, 温度に対してプロットした結果を示す。ピークaはPdSWCNHの活性を表し,ほかの試料に比べ非常に高い触媒活性を 示す。一方, PVP被覆したSWCNH (ピークb) は面積比から考元 ると半分以下の活性となる。Pd-oxSWCNHのピーク cは2つか らなり, XPSの結果と併せ, $\mathrm{PdO}_{2}$ と金属 $\mathrm{Pd}$ による反応であると 帰属できた。やはり酸素があるほうがより低い温度を反応促進 させるが, 水素生成量はPd-SWCNH ほど多くはなく, Fig.9 の水 生成の場合と似た結果である。したがって, 担体としては酸素の ないSWCNHを用いるのがよく, PVPを被覆しないほうが, 活性 の高い金属ナノ粒子を比較的活性の高いままで安定化させてい ると結論できる。

\section{6. おわりに}

最初に記述したように, 粒子がナノレベルになると表面は非常 に活性状態となり，同種の粒子が結合して大きくなったり，ある いは, 酸素結合して酸化物になったりして, 金属のままでは安定 で存在しにくくなる。ナノ細孔性白金もナノ細孔性パラジウム も微量の炭素が含まれており，これがナノ細孔性を保持するのに重 要であることがわかった。いわゆる金属ナノ粒子の調製におい て, 高分子や界面活性剂などの有機分子がメタルナノ粒子を保護 し酸化や焼結を防ぐが, 本稿で示されたナノ細孔性メタルでは, 3.抢よび4.で記述したように微量炭素が金属表面を被覆し, 酸化 や焼結を防いでいると考えられている。

このようにナノ細孔性メタルを合成するうえでは,ナノレベル の耐酸化性や耐焼結性機構を効果的に作用させることがキーポイ ントになると思われる。このような保護機構があまり強すぎて 
も，活性であるというナノ構造性の特長を減じることとなる。機 能性との関連からそれらのバランスをコントロールすることが重 要である。SWCNHや単層カーボンナノチューブのような特異な 電子状態にある炭素への金属ナノ粒子の担持はさらに興味深い現 象や機能をもたらすことが示されつつある。触媒反応などさらな る実験例の蓄積も必要であろう。それら結果を総括することで, 基本原理が明らかになると思われるが, 理論的解析やコンピュー タシミュレーションによるアプローチも欠かせないものである。 今後これらの協同的な取り組みを発展させていきたい。

\section{文 献}

1) T. Teranishi and M. Miyake, Chem. Mater. 10 (1998) 594-600.

2) E. Bekyarova, A. Hashimoto, M. Yudasaka, Y. Hattori, K. Murata, H. Kanoh and K. Kaneko, J. Phys. Chem. B 109 (2005) 3711-3714.

3) G. S. Attard, C. G. Göltner, J. M. Corker, S. Henke and R. H. Templer, Angew. Chem. Int. Ed. 36 (1997) 1315-1317.

4) G. S. Attard, P. N. Bartlett, N. R. B. Coleman, J. M. Elliot, J. R. Owen and J. H. Wang, Science 278 (1997) 838-840.

5) G. S. Attard, N. R. B. Coleman and J. M. Elliott, Stud. Surf. Sci. Catal. 117 (1998) 89-94.

6) G. S. Attard, P. N. Bartlett, N. R. B. Coleman, J. M. Elliott and J. R. Owen, Langmuir 14 (1998) 7340-7342.

7) J. M. Elliot, P. R. Birkin, Ph. N. Bartlett and G. S. Attard, Langmuir 15 (1998) 7411-7415.

8) J. M. Elliott, G. S. Attard, P. N. Bartlett, N. R. B. Coleman, D. A. S. Merckel and J. L. Owen, Chem. Mater. 11 (1999) 3602-3609.

9) G. S. Attard, S. A. A. Leclerc, S. Maniguet, A. E. Russell, I. Nandhakumar, B. R. Gollas and P. N. Bartlett, Microporous. Mesoporous. Mater. 4445 (2001) 159-163.

10) H. Wakayama and Y. Fukushima, Chem. Commun. (1999) 391-391.

11) H. Wakayama and Y. Fukushima, Ind. Eng. Chem. Res. 39 (2000) 4641-4645.
12) M. Asai, T. Onoe, H. Kanoh and K. Kaneko, Colloids and Surfaces A : Physicochem. Eng. Aspects 253 (2005) 199-202.

13) Y. Hattori, T. Konishi, H. Kanoh, S. Kawasaki and K. Kaneko, Adv. Mater. 15 (2003) 529-531.

14) Z. Liu, Y. Sakamoto, T. Ohsuna, K. Hiraga, O. Terasaki, C. -H. Ko, H. -J. Shin and R. Ryoo, Angew. Chem. Int. Ed. 39 (2000) 3107-3110.

15) H. J. Shin, C. H. Ko and R. Ryoo, J. Mater. Chem. 11 (2001) 260-261.

16) G. Sakai, T. Yoshimura, S. Isohata, M. Uota, H. Kawasaki, T. Kuwahara, D. Fujikawa and T. Kijima, Adv. Mater. 19 (2007) 237-241.

17) T. Itoh, T. Onoe, M. Asai, T. Ohba, K. Kaneko and H. Kanoh, submitted.

18) K. Hasegawa, T. Itoh, Y. Hattori, S. Utsumi, K. Urita, D. Noguchi, M. Arai, T. Ohba, K. Kaneko and H. Kanoh, to be submitted.

19) A. Hashimoto, H. Yorimitsu, K. Ajima, K. Suenaga, H. Isobe, J. Miyawaki, M. Yudasaka, S. Iijima and E. Nakamura, Proc. Nati. Acad. Sci. USA 101 (2004) 8527-8530.

20) R. Yuge, T. Ichihashi, Y. Shimakawa, Y. Kubo, M. Yudasaka and S. Iijima, Adv. Mter. 16 (2004) 1420.

21) K. Murata, M. Yudasaka and S. Iijima, Carbon 44 (2006) 818-820.

22) J. Miyawaki, M. Yudasaka, H. Imai, H. Yorimitsu, H. Isobe, E. Nakamura and S. Iijima, J. Phys. Chem. B 110 (2006) 5179-5181.

23) S. Utsumi, K. Urita, H. Kanoh, M. Yudasaka, K. Suenaga, S. Iijima and K. Kaneko, J. Phys. Chem. B 2006 (110) 7165-7170.

24) T. Itoh, H. Danjo, W. Sasaki, K. Urita, E. Bekyarova, M. Arai, T. Imamoto, M. Yudasaka, S. Iijima, H. Kanoh and K. Kaneko, Carbon 46 (2008) 172-175.

25) T. Itoh, K. Urita, E. Bekyarova, M. Arai, M. Yudasaka, S. Iijima, T. Ohba, K. Kaneko and H. Kanoh, J. Colloid Interface Sci. 322 (2008) 209-214.

26) S. Iijima, M. Yudasaka, R. Yamada, S. Bandow, K. Suenaga, F. Kokai and K. Takahashi, Chem. Phys. Lett. 309 (1999) 165-170.

27) S. Utsumi, J. Miyawaki, H. Tanaka, Y. Hattori, T. Itoi, N. Ichikuni, H. Kanoh, M. Yudasaka, S. Iijima and K. Kaneko, J. Phys. Chem. B 109 (2005) 14319-14324. 